DOI: https://doi.org/10.47405/mjssh.v5i6.430

\begin{tabular}{|c|c|}
\hline 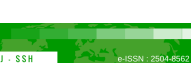 & Malaysian Journal of Social Sciences and Humanities (MJSSH) \\
\hline Malaysian Journal of & Volume 5, Issue 6, June 2020 \\
\hline $\begin{array}{l}\text { Humanities } \\
\text { (MJ - sSH) }\end{array}$ & e-ISSN : 2504-8562 \\
\hline$-\infty$ & $\begin{array}{l}\text { Journal home page: } \\
\text { www.msocialsciences.com }\end{array}$ \\
\hline
\end{tabular}

\title{
Struktur Tripolar dan Politik Antarabangsa Asia Pasifik
}

\author{
Mohd. Noor Yazid ${ }^{1}$ \\ 1Program Hubungan Antarabangsa, Fakulti Sains Sosial dan Kemanusiaan, Universiti Malaysia Sabah (UMS) \\ Correspondence: Mohd. Noor Yazid (mohdnoor@ums.edu.my)
}

\begin{abstract}
Abstrak
Artikel ini membincangkan struktur tripolar yang berlaku di rantau Asia Pasifik daripada tahun 1971 hingga 1991 dan impak terhadap percaturan kuasa politik antarabangsa di rantau Asia Pasifik. Struktur tripolar adalah struktur kuasa yang terdiri daripada tiga kuasa iaitu Amerika Syarikat, Soviet Union dan China. Ianya penting dalam memamhi percaturan kuasa yang berlaku di rantau Asia Pasifik dari tahun 1971 hingga 1991. Analisis percaturan kuasa di rantau Asia Pasifik selepas Perang Dingin berakhir juga perlu dikatkan dengan struktur tripolar yang berlaku dalam tahun-tahun 1971-1991.
\end{abstract}

Kata kunci: struktur tripolar, bipolar, Amerika Syarikat, Sovient Union, China

\section{The Tri-Polarity Structure and International Politics of the Asia Pacific}

\begin{abstract}
This article discusses the tri-polarity structure in the Asia Pacific region from 1971 until 1991 and the impact to the power configuration in the Asia Pacific region. Tri-polarity structure in the Asia Pacific is power structure which based on three major powers: the United States, Soviet Union and China. This power structure is important in understanding power configuration in the Asia Pacific region from 1971 until 1991. The tri-polarity structure also important in analyzing the post-Cold War of the Asia Pacific power configuration.
\end{abstract}

Keywords: tri-polarity structure, bipolarity, The United States, Soviet Union, China

\section{Pengenalan}

Artikel ini membincangkan struktur tripolar di rantau Asia Pasifik iaitu satu struktur kuasa yang didominasi oleh tiga kuasa utama iaitu Amerika Syarikat, Soviet Union dan China dari tahun 1971 hingga 1991 dan impaknya kepada rantau Asia Pasifik. Bagaimana struktur tripolar ini mempengaruhi percaturan kuasa di rantau ini? Bagaimana pentingnya struktur tripolar ini kepada politik serantau Asia Pasifik yang dapat dilihat dalam beberapa aspek; (i) Apa hubungan struktur tripolar ini (1971-1991) kepada struktur politik rantau Asia Pasifik selepas berakhirnya Perang Dingin 1991; (ii) hubungan struktur tripolar dan kebangkitan ekonomi China dan sebagai sebuah kuasa besar. Struktur tripolar adalah satu tempoh masa yang penting yang mempunyai pengaruh yang besar kepada perjalanan politik serantau, bukan sahaja dalam era Perang Dingin tetapi juga selepas Perang Dingin berakhir. 
Tanpa terbentuknya struktur tripolar adalah sukar bagi China Komunis mencapai pertumbuhan ekonomi pembangunan yang pesat dalam tahun-tahun 1980-an dan 1990-an dan menjadi kuasa ekonomi kedua terbesar dunia pada akhir tahun 2010. Tanpa era struktur bersifat tripolar ini (khususnya fasa kedua struktur tripolar, 1980-1991), adalah sukar bagi ekonomi China untuk membangun dengan begitu cepat. Tanpa kekuatan ekonomi, adalah tidak memungkinkan bagi China bagi memperbesarkan kekuatan tenteranya yang akhirnya menjadi salah sebuah kuasa tentera yang kuat. Kekuatan tentera dan ekonomi China adalah penting dalam menjelaskan struktur kuasa di rantau Asia Pasifik selepas berakhirnya Perang Dingin 1991. Asia Pasifik tidak begitu mudah bertukar kepada struktur unipolar (sebagaimana yang berlakunya perubahan struktur politik di benua Eropah) apabila Perang Dingin berakhir dengan kejatuhan kuasa Soviet Union. Struktur tripolar yang terbentuk dalam tahun-tahun 1971-1991 adalah penting dalam menjelaskan bagaimana berbezanya rantau Asia Pasfik dengan rantau lain dunia, khususnya benua Eropah. Peranan dan kedudukan kuasa China penting dalam menjelaskan struktur kuasa yang terbentuk di rantau Asia Pasifik selepas era Perang Dingin.

\section{Objektif Kajian}

Kajian ini mempunyai tiga objektif utama, iaitu:

i. Menerangkan pentingnya struktur tripolar dalam memahami politik antarabangsa Asia Pasifik.

ii. Membincangkan hubungan antara struktur tripolar 1971-1991 dan struktur politik serantau yang terbentuk selepas berakhirnya Perang Dingin 1991.

iii. Menganalisis hubungan antara kewujudan struktur tripolar, kebangkitan kuasa China sebagai sebuah kuasa besar dan impak kepada struktur politik rantau Asia Pasifik selepas berakhirnya Perang Dingin 1991.

\section{Skop Kajian}

Skop kajian ini adalah menganalisa percaturan kuasa dan hubungan antara tiga kuasa besar dalam era struktur tripolar iaitu bermula dari tahun 1971 hingga 1991 dan impak kepada regional politik dan percaturan kuasa dalam dekad pertama selepas berakhirnya Perang Dingin iaitu dari tahun 1991 hingga 2001.

\section{Metod Kajian}

Kajian ini menggunakan data-data sekunder daripada buku, artikel jurnal, sumber internet dan seumpamanya. Ianya dianalisis dengan menggunakan kaedah kualitatif.

\section{Pendekatan Teori}

Pada asasnya kajian ini menggunakan teori Structural Realism (Neo-realism). Ianya melihat bagimana hubungan yang berlaku antara dan pengaruh faktor sistemik dalam mempengaruhi percaturan kuasa politik di peringkat state dan juga di peringkat regional. State tidak bebas bertindak dan keputusan serta tindakan sesebuah state adalah mempunyai hubungan dan pengaruh yang berlaku di peringkat sistemik (antarabangsa). Jadi percaturan kuasa yang berlaku di peringkat state dan regional adalah kuat dipengaruhi oleh faktor sistemik. Sesebuah state dan sesebuah regional adalah tidak bebas sepenuhnya dalam bertindak dan membuat keputusan kerana struktur antarabangsa mempengaruhi tindakan mereka. ${ }^{\text {i }}$

Struktur tripolar yang terbentuk di rantau Asia Pasifik (percaturan kuasa antara Amerika Syarikat, Soviet Union dan China) adalah berasaskan Structural Realism. Asas tripolar adalah tidak bebas daripada faktor antarabangsa yang berlaku iaitu konflik dan percaturan kuasa antara dua kuasa utama di 
peringkat antarabangsa iaitu Amerika Syarikat dan Soviet Union. ${ }^{\text {ii }}$ Ini dibincangkan dengan lebih lanjut dalam bahagian struktur Tripolar di bawah.

\section{Kepentingan Kajian}

Kajian ini penting dalam memahami struktur politik regional di rantau Asia Pasifik selepas berakhirnya Perang Dingin 1991. Kenapa struktur politik rantau Asia Pasifik selepas berakhirnya Perang Dingin berbeza dengan rantau lain dunia, khususnya dengan benua Eropah? Kenapa struktur politik rantau Eropah mempunyai perbezaan yang jelas iaitu bersifat bipolar dalam era Perang Dingin dan berubah kepada struktur unipolar selepas berakhirnya Perang Dingin? Kenapa rantau Asia Pasifik tidak terus berubah kepada struktur unipolar sebagaimana yang berlaku di benua Eropah apabila Soviet Union runtuh dan berakhirnya Perang Dingin? Jawapannya ialah faktor kewujudan kuasa China Komunis. Bagaimana kuasa China Komunis berupaya bangkit dengan cepat dan menjadi sebuah kuasa besar? Bilakah pembangunan pesat (rapid development) China Komunis bermula? Bagaimana struktur tripolar 1971-1991 penting dalam menjelaskan kebangkitan dan pembangunan pesat ekonomi China komunis dalam tahun-tahun 1980-an dan 1990-an? Tempoh masa bermula dari tahun 1980 mempunyai pengaruh yang besar kepada tahap pembangunan dan kedudukan China pada hari ini. Adakah mungkin China menjadi sebuah kuasa ketenteraan dan kekuatan ekonomi kini tanpa melalui apa yang berlaku dalam era tripolar? Jadi kajian ini penting dalam memahami ekonomi politik dan percaturan kuasa pasca Perang Dingin rantau Asia Pasifik.

\section{Struktur Tripolar}

\section{Apakah yang di maksudkan dengan Struktur Tripolar?}

Struktur Tripolar adalah merujuk kepada satu keadaan struktur politik yang terdiri daripada tiga buah kuasa dominan yang memainkan peranan penting dalam sesuatu wilayah tertentu dalam sesuatu tempoh masa tertentu. ${ }^{\text {iii }}$ Satu contoh struktur tripolar ialah percaturan kuasa politik antarabangsa yang berlaku di rantau Asia Pasifik dalam tempoh masa bermula daripada tahun 1971 hingga runtuhnya Soviet Union dalam tahun 1991. Tahun 1971 itu dirujuk kepada pengiktirafan China Komunis sebagai sebuah kuasa besar iaitu bermula dengan lawatan Henry Kisingger pada Julai 1971 dan Presiden Richard Nixon pada Februari $1972 .{ }^{\text {iv }}$ Peristiwa ini kemudiannya membawa kepada pengembalian kerusi tetap Majlis Keselamatan kepada China Komunis pada tahun 1972. China telah memainkan peranan sebagai sebuah kuasa besar yang diiktiraf oleh dunia. Dalam tempoh masa ini tiga buah kuasa besar ini iaitu Amerika Syarikat, Soviet Union dan China Komunis memainkan peranan penting dalam percaturan kuasa di rantau Asia Pasifik. ${ }^{\mathrm{v}}$ Sebelum tahun 1971 China komunis tidak diiktiraf sebagai salah sebuah kuasa besar di peringkat antarabangsa dan regional. Rantau Asia Pasifik sebelum terbentuknya struktur tripolar di diminasi oleh dua buah kuasa besar iaitu Amerika Syarikat dan Soviet Union. Perubahan daripada struktur bipolar kepada struktur tripolar bermula pada tahun 1972 apabila China Komunis diiktiraf oleh dunia sebagai sebuah kuasa besar.

Dua Fasa Struktur Tripolar di rantau Asia Pasifik: Struktur tripolar yang mewarnai percaturan kuasa di rantau Asia Pasifik dari tahun 1971 hingga 1991 dapat dibahagikan kepada dua fasa yang berbeza iaitu; fasa pertama bermula dari tahun 1971 hingga 1979 dan; fasa kedua bermula dari tahun 1980 hingga tahun 1991. Kedua-dua fasa ini mempunyai perbezaan tertentu. ${ }^{\text {vi }}$

\section{Struktur Tripolar fasa I, 1971-1979}

Dalam struktur tripolar fasa pertama ini, Amerika Syarikat menjadi kuasa paksi (pivot power). Amerika Syarikat mempunyai hubungan yang baik dengan kedua-dua buah kuasa, Soviet Union dan China Komunis. Dalam tempoh masa fasa pertama ini hubungan antara Soviet Union dan China Komunis adalah buruk. Amerika Syarikat perlu mengawal dan mengekalkan hubungan buruk antara China Komu nis dan Soviet Union ini. Hubungan buruk antara China Komunis dan Soviet Union ini 
penting dalam mengekalkan kestabilan dalam struktur tripolar. Amerika Syarikat perlu mengawal daripada terbentuknya hubungan baik antara Soviet Union dan China Komunis. ${ }^{\text {vii }}$ Dalam masa yang sama Amerika Syarikat perlu membentuk dan mengekalkan hubungan yang baik dengan Soviet Union dan juga hubungan yang baik dengan China Komunis. Dalam tempoh masa fasa pertama ini China Komunis mempunyai hubungan yang baik dengan Amerika Syarikat dan mempunyai hubungan yang buruk dengan Soviet Union. Keadaan ini berubah selepas dari tahun 1979, apabila fasa kedua struktur tripolar bermula.

\section{Struktur Tripolar fasa II, 1980-1991}

Struktur tripolar fasa kedua di rantau Asia Pasifik bermula selepas daripada tahun 1979 hingga berakhirnya Perang Dingin pada Disember 1991. Dalam tempoh masa fasa kedua ini, Amerika Syarikat tidak lagi menjadi kuasa paksi (pivot power). Peranan kuasa paksi telah diambil alih oleh China Komunis. China Komunis mempunyai hubungan yang baik dengan dua buah kuasa, iaitu dengan Amerika Syarikat dan Soviet Union. Dalam fasa kedua ini Soviet Union dan Amerika Syarikat mempunyai hubungan yang buruk. Tindakan Soviet Union campurtangan ke atas Afghanistan pada bulan Disember 1979 telah mempengaruhi hubungan antara Amerika Syarikat dan Soviet Union. ${ }^{\text {vii }}$ Tindakan Soviet Union ke atas Afghanistan dianggap oleh Amerika Syarikat sebagai melanggar persetujuan "Détente" yang dipersetujui oleh kedua-dua belah pihak sebelum ini. Hubungan buruk berlaku antara Amerika Syarikat dan Soviet Union akibat daripada apa yang berlaku di Afghanistan.

Sebagai kuasa paksi dalam fasa kedua ini, China Komunis mempunyai hubungan baik dengan Soviet Union dan Amerika Syarikat. China Komunis telah memperbaiki hubungan diplomatiknya dengan Amerika Syarikat dan membentuk hubungan yang lebih daripada sebelumnya dengan Soviet Union. Dalam fasa pertama (1971-1979) China Komunis mempunyai hubungan yang buruk dengan Soviet Union. Hubungan buruk yang berlaku mulai akhir tahun 1979 antara Amerika Syarikat dan Soviet Union menpengaruhi dasar luar Amerika Syarikat terhadap China Komunis. ${ }^{i x}$ Deng Xiao-Peng, presiden China Komunis mengadakan lawatan rasmi ke Amerika Syarikat pada bulan Januari 1979. Amerika Syarikat telah memberi sokongan kepada China Komunis dalam konflik China dengan Vietnam pada awal tahun 1979. Amerika Syarikat juga telah membantu China Komunis dalam pembangunan ekonomi dan tekonologi moden yang sophisticated. ${ }^{\mathrm{x}}$ Hubungan ekonomi dan perdagangan China Komunis dengan Negara-negara Barat bertambah baik dengan dramatik dalam fasa kedua ini. Pelaburan daripada Negara-negara Barat masuk ke China. Kerjasasama ekonomi antara China dan Negara-Negara Barat berkembang pesat di bawah pentadbiran Deng Xiao-Peng. Special Economi Zone dibentuk oleh Deng Xiao-Peng. Mulai awal tahun 1980-an ekonomi yang berteraskan pasaran bebas telah berkembang di China. Selepas kematian Deng Xiao-Peng pada tahun 1997, pengganti Deng Xiao-Peng iaitu Jiang Zemin meneruskan dasar ekonomi yang dimulakan oleh Deng. Hubungan ekonomi dan pelaburan daripada Negara-negara Barat terus berjalan. Perubahan dasar ekonomi yang bermula dalam tahun-tahun awal struktur tripolar fasa kedua ini telah mempengaruhi perubahan dan kemajuan ekonomi China Komunis.

\section{Struktur Tripolar dan Kebangkitan Kuasa Ekonomi China}

Tempoh masa struktur tripolar dari tahun 1971-1991 adalah satu tempoh masa yang penting dalam pembangunan ekonomi China Komunis. Hubungan baik yang berlaku antara China dan Amerika Syarikat dalam tempoh masa struktur tripolar (Amerika Syarikat sebagai kuasa hegemoni) telah membuka peluang ekonomi antarabangsa kepada China. Hubungan perdagangan China berkembang pesat khususnya dengan Negara-negara yang berada dalam limgkungan pengaruh ekonomi Amerika Syarikat (American economic sphere) yang agak terbatas sebelum daripada era struktur tripolar. Dalam era struktur tripolar ini, khususnya semasa pentadbiran Deng Xiao-Peng dari tahun 1978 hingga 1997, telah berlaku satu transformasi dasar ekonomi China iaitu daripada dasar ekonomi tertutup kepada dasar ekonomi terbuka. ${ }^{\text {xi }}$ China telah memperkenalkan ekonomi pengeluarannya kepada ekonomi pasaran luar iaitu meluaskan kegiatan ekonomi bukan sahaja kepada keperluan domestik tetapi juga kepada pasaran antarabangsa. ${ }^{\text {xii }}$ Banyak polisi ekonomi yang terbuka telah bermula sejak awal tahun 1980-an bagi menggalakkan pembangunan dan pertumbuhan ekonomi China. Hubungan ekonomi 
dengan Amerika Syarikat, Negara-negara Eropah Barat dan Jepun berlaku dengan dramatik. ${ }^{\text {xiii }}$ Deng Xiao-Peng menggalakkan pelaburan asing ke China. Ideologi politik telah diketepikan oleh Deng dalam dasar baru pembangunan ekonomi China. Mulai awal tahun 1980-an pelaburan asing dari Negara-negara Eropah Barat, Japan, Hong Kong dan Taiwan telah mencurah masuk ke China Komunis. Perubahan dalam aspek ekonomi ini mempunyai hubungan dengan perubahan struktur politik wilayah yang bersifat tripolar. Kedudukan China Komunis sebagai kuasa paksi (pivot power) dan hubungan baik dengan Amerika Syarikat khususnya dalam fasa kedua tripolar mempengaruhi perubahan dan perkembangan ekonomi China Komunis.

Hubungan perdagangan antara China Komunis dengan Jepun meningkat dengan pesat sejak awal tahun 1980-an. Menjelang pertengahan tahun 1980-an, Jepun adalah rakan perdagangan kedua terbesar bagi China Komunis (di belakang Amerika Syarikat). China Komunis membekalkan kepada Jepun petroleum, ranag batu dan lain-lain bahan mentah yang diperlukan oleh Jepun, manakala Jepun pula membekalkan kepada China barangan modal, teknologi dan barangan perkilangan yang diperlukan oleh China Komunis untuk tahap pelancaran ekonomi China.

Perkembangan ekonomi China Komunis dalam akhir tahun 1970-an dan tahun 1980-an mempunyai hubungan yang rapat dengan struktur tripolar yang menguasai percaturan kuasa di rantau Asia Pasifik. Hubungan ekonomi China Komunis yang berkembang dan meningkat dengan pesat dengan Amerika Syarikat dan negara-negara di bawah lingkungan ekonomi Amerika Syarikat (American economic sphere) tidak mungkin berlaku tanpa wujudnya strukutur tripolar dan hubungan baik China Komunis dengan Amerika Syarikat. Sokongan Amerika Syarikat terhadap China Komunis dengan membantu menggalakkan kekuatan ekonomi dan teknologi kepada China adalah sebahagian daripada strategi pertahanan Amerika Syarikat terhadap Soviet Union. Kedudukan China yang lebih kuat akan mampu menyekat perluasan kuasa Soviet Union di rantau Asia Pasifik. Kedudukan China yang kuat, akan membolehkan keseimbangan kuasa terbentuk. Jadi pertumbuhan dan pembangunan ekonomi China Komunis yang berlaku adalah mempunyai hubungan yang sangat rapat dengan percaturan kuasa politik yang terbentuk di rantau Asia Pasifik. Sekiranya struktur tiga kuasa ini tidak terbentuk, belum tentu pertumbuhan ekonomi China Komunis tumbuh dengan pesat dalam tahun-tahun 1980-an dan 1990-an.

\section{Struktur Tripolar dan Kesan kepada Struktur Politik Rantau Asia Pasifik Selepas berakhirnya Perang Dingin}

Struktur tripolar yang terbentuk dalam tahun-tahun 1971-1991 mempunyai kesan yang besar terhadap struktur politik serantau Asia Pasifik selepas berakhirnya Perang Dingin 1991. Kedudukan China Komunis sebagai sebuah kuasa yang kuat telah mempengaruhi struktur kuasa politik regional dalam era pasca Perang Dingin. Sekiranya tidak wujudnya kuasa China Komunis maka struktur kuasa yang terbentuk adalah berbeza. Dengan keruntuhan Soviet Union pada tahun 1991, Amerika Syarikat akan muncul sebagai sebuah kuasa tunggal di rantau Asia Pasifik. Tetapi struktur unipolar tidak terbentuk kerana wujudnya kuasa China Komunis yang kuat di rantau Asia Pasifik. Penerapan masuk unsurunsur demokrasi yang selari dengan dan mendapat sokongan Amerika Syarikat ke dalam masyarakat China dalam akhir tahun-tahun 1980-an mengalami kegagalan. Kegagalan gerakan Tiananmen Square Jun 1989 dilihat sebagai kekuatan China Komunis mempertahankan ideologi dan kedudukan ekonominya yang kuat. Kejayaan Deng mengalahkan gerakan pro-demokrasi ini menunjukkan kedudukan ideologi dan ekonomi China yang kuat. China adalah berbeza dengan Negara-negara Komunis Eropah Timur yang berjaya dikuasai oleh gerakan pro-demokrasi. Tidak ada sebuah Negara yang kuat kedudukan ekonomi yang kuat di Eropah Timur sebagaimana Kedudukan dan kekuatan ekonomi China di Asia Pasifik.

Kedudukan dan situasi di rantau Asia Pasifik adalah berbeza dengan struktur kuasa yang berlaku di benua Eropah. Benua Eropah sebelum berakirnya Perang Dingin adalah bersifat bipolar. Garis sempadan struktur bipolar sangat jelas di benua Eropah, iaitu; Eropah Barat berasaskan ideologi demokrasi demokrasi-kapitalis di pengaruhi oleh Amerika Syarikat dibawah pengawalan NATO, manakala Eropah Timur dipengaruhi oleh Soviet Union di bawah kawalan keselamatan dan ketenteraan oleh Warsaw Pact. Apabila kuasa Soviet Union berakhir pada tahun 1991 dan Warsaw Pact dibubarkan 
hanya tinggal sebuah kuasa tunggal iaitu Amerika Syarikat yang menguasai seluruh benua Eropah. Hanya sebuah pakatan keselamatan iatu NATO dan Amerika Syarikat menguasai dan mengawal seluruh Eropah (Eropah Barat dan Eropah Timur). Struktur unipolar terbentuk di benua Eropah. Negara-negara bekas komunis Eropah Timur kemudiannya satu demi satu menjadi anggota NATO. Pengkalan tentera NATO ditempatkan di bekas negara-negara komunis Eropah Timur. Tindakan segera dilakukan oleh Amerika Syarikat dan NATO menguasai seluruh benua Eropah adalah perlu dalam strategi pengukuhan kuasa sebelum berlaku kebangkitan semula Russia.

Aspek lain yang berbeza antara Asia Pasifik dan Eropah adalah kedudukan Amerika Syarikat dan bentuk perjanjian keselamatan antara Amerika Syarikat dan Negara-negara sekutunya di kedua-dua rantau tersebut. ${ }^{\text {xiv }}$ Di benua Eropah pakatan keselamatan yang dibentuk adalah bersifat multilateral, iaitu NATO, tetapi berbeza dengan pakatan keselamatan yang dibentuk oleh Amerika Syarikat (khususnya di rantau Timur Laut Asia). Dengan faktor regional dan halangan geo-politik yang terdapat di rantau Timur Laut Asia, Amerika Syarikat tidak dapat membentuk sebuah pakatan yang bersifat multilateral sebagaimana di benua Eropah. Bagi memenuhi keperluan regional dan pakatan yang lebih berkesan bagi mencapai matlamat keselamatan dan pertahanan Amerika Syarikat di Timur Laut Asia pakatan keselamatan yang paling sesuai adalah berbentuk bilateral. Tiga buah pakatan pertahanan yang dibentuk adalah Pakatan Pertahanan Amerika Syarikat-Jepun 1951, Pakatan Pertahanan Amerika Syarikat-Korea Selatan 1953 dan Pakatan Pertahanan Amerika Syarikat-Taiwan 1954. ${ }^{\mathrm{xv}}$ Pakatan pertahanan yang bersifat bilateral ini yang dibentuk pada tahun-tahun awal Perang Dingin bermula terus kekal dan tetapi mempunyai peranan sehingga selepas berakhirnya Perang Dingin 1991.

\section{Struktur Tripolar dan impak kepada Peraturan Kuasa Regional}

Impak struktur tripolar ke atas percaturan kuasa dan politik serantau selepas berakhirnya Perang Dingin adalah sangat jelas. Dengan kewujudan tiga buah kuasa besar utama dalam era tripolar 1971-1991, masih ada dua buah kuasa lagi dalam struktur kuasa di rantau Asia Pasifik selepas Soviet Union runtuh pada kahir tahun 1991. Kuasa yang masih dominan selepas 1991 adalah adalah Amerika Syarikat dan China Komunis.

Kuasa China Komunis mempunyai kedudukan yang semakin kuat selepas tahun 1991, berbanding dengan dua dekad sebelumnya. Dalam masa tahun-tahun awal struktur tripolar bermula kedudukan ekonomi dan ketenteraan China Komunis tidaklah begitu kuat. Dengan percaturan kuasa yang bersifat tripolar banyak memberi keuntungan kepada China komunis membina dan mengukuhkan kedudukan ekonomi. Polisi dan pertumbuhan ekonomi China Komunis mulai awal tahun 1980-an dan 1990-an memberi sumbangan besar kepada kedudukan China yang lebih kukuh dalam politik dan ketenteraan antarabangsa. China telah menjadi ekonomi kedua terbesar selepas Amerika Syarikat pada akhir tahun 2010. Kekuatan ekonomi China ini telah diterjemahkan kepada kekuatan ketenteraan.

\section{Struktur Politik Rantau Asia Pasifik dan Benua Eropah Selepas Perang Dingin: Kenapa berbeza?}

Perbezaan struktur politik selepas berakhirnya Perang Dingin antara benua Eropah dan rantau Asia Pasifik adalah jelas. Struktur politik di benua Eropah berubah daripada struktur bersifat bipolar (19471991) kepada struktur unipolar selepas berakhirnya Perang Dingin pada tahun $1991 .{ }^{\text {xvi }}$ Perubahan struktur politik di benua Eropah dapat dilihat dengan jelas. Perkembangan ekonomi dan politik yang berlaku di Negara-negara komunis sejak akhir tahun 1980-an menyebabkan runtuhnya negara-negara komunis Eropah Timur. Kedudukan ekonomi Soviet Union yang lemah mulai pertengahan tahun 1980an membuka peluang kepada kebangkitan ideologi anti-komunis (pro-demokrasi) di Negara-negara komunis Eropah Timur. Regim komunis jatuh satu demi satu pada akhir than 1980-an dan diganti oleh pentadbiran demokrasi-kapitalis. Akhirnya pada awal tahun 1990-an berlaku perubahan menyeluruh Negara komunis Eropah Timur berubah daripada Negara yang berpegang kepada idelogi komunis yang dilindungi oleh Soviet Union kepada negara berideologi demokrasi-kapitalis. Jerman Barat dan Jerman Timur yang terpisah sejak awal era Perang Dingin telah bergabung semula pada Jun 1989 sebagai satu 
Jerman berasaskan ideologi demokrasi-kapitalis. Warsaw Pact sebagai sebuah pakatan pertahanan yang melindungi keselamatan negara-negara komunis Eropah Timur telah dibubarkan pada Julai 1991. Negara-negara bekas komunis ini kemudiannya menganggotai NATO dan menjadi sebahagian daripada anggota European Union. .vii $^{\text {ni }}$

Perkembangan politik dan percaturan kuasa serta struktur regional yang terbentuk selepas berakhirnya Perang Dingin di rantau Asia Pasifik berbeza dengan apa yang berlaku di benua Eropah. Daripada struktur tripolar yang terbetuk dari tahun 1971-1991, struktur politik regional Asia Pasifik tidak terus berubah kepada struktur unipolar. ${ }^{\text {xviii }}$ Amerika Syarikat bukan satu-satu kuasa utama yang mendominasi rantau Asia Pasifik selepas tahun 1991. Korea Utara dan Korea Selatan masih terpisah seperti dalam era Perang Dingin. Penyatuan antara Korea Utara dan Korea Selatan dilihat tidak akan berlaku dengan mudah sebagaimana belakunya penyatuan antara Jerman Barat dan Jerman Timur dalam tahun 1989. Perjanjian Keselamatan yang dimeterai antara Amerika Syarikat dan Negara-negara sekutunya di rantau Timur Laut Asia pada tahun-tahun awal Perang Dingin masih berjalan dan berfungsi dengan efektif seerti sebelum Perang Dingin berakhir. The U.S-Japan Alliance yang ditandatangani pada September 1951, The US-South Korea Security Agreement yang ditandatangani dalam tahun 1953 dan The U.S- Republic of China (Taiwan) yang ditandatangani dalam tahun 1954 masih berjalan dan masih berfungsi. Ketiga-tiga perjanjian keselamatan antara Amerika Syarikat dan Negara-negara sekutunya ini masih dilihat berguna dan mungkin dibubarkan. Struktur politik serantau di Asia Pasifik, khususnya di Timur Laut Asia tidak berlaku perubahan kepada struktut unipolar yang didominasi oleh satu kuasa besar utama, sebagaimana yang berlaku di benua Eropah.

Apakah faktor yang bertanggungjawab dan mampu menjelaskan bagaimana struktur politik di rantau Asia Pasifik ini terbentuk? Jawapannya adalah kewujudan kuasa China Komunis yang kuat dalam aspek politik/ketenteraan dan kedudukan ekonomi yang teguh. ${ }^{x i x}$ China Komunis mengalami pengalaman ekonomi yang berbeza dengan Negara-negara komunis Eropah Timur dan juga dengan pengalaman ekonomi yang dilalui oleh Soviet Union. ${ }^{\mathrm{xx}}$ Situasi ekonomi Negara-negara komunis Eropah Timur dan Soviet Union mengalami masalah sejak pertengahan tahun 1980-an. Keadaan berbeza yang berlaku di China dalam tempoh masa ini. Dalam tempoh masa ini China memulakan satu reformasi ekonomi di bawah pimpinan Presiden Deng Xiao-Peng. ${ }^{\text {xxi }}$ China membina hubungan yang baik dengan Amerika Syarikat dan Negara-negara sekutu Amerika Syarikat di Eropah dan juga Jepun dalam operasi kuasa yang bersifat tripolar. Hubungan baik China dengan Negara-negara Barat telah memberikan kesan yang positif kepada pertumbuhan dan pembangunan ekonomi China. Apa yang berlaku di China dalam mulai akhir tahun 1970-an telah membuka laluan kepada China menjadi sebuah kuasa ekonomi dunia selepas berakhirnya Perang Dingin. ${ }^{x x i i}$ Reformasi ekonomi yang dilakukan oleh presiden Deng Xiao-peng memberikan impak yang besar kepada kebangkitan dan kekuatan ekonomi China. Dasar yang dimulakan oleh Deng di teruskan oleh Presiden Jiang Zemin selepas kematiannya dalam tahun 1997.

Struktur politik di benua Eropah berubah dengan jelas daripada bipolar kepada unipolar selepas berakhirnya Perang Dingin, tetapi perubahan struktur secara dramatik tidak berlaku di rantau Asia Pasifik. Struktur tripolar yang mendominasi rantau Asia Pasifik dari tahun 1971 hingga 1991 tidak berlaku perubahan yang dramatik secara jelas selepas Perang Dingin berakhir. Adalah sukar bagi menyatakan yang Asia Pasifik selepas Perang Dingin berakhir bersifat 'bipolar' sebagaimana benua Eropah dalam era Perang Dingin dan juga tidak tepat sama sekali untuk menyatakan Asia Pasifik bersifat unipolar.

Tidak tepat bagi menyatakan Asia Pasifik bersifat 'bipolar' kerana bipolar adalah merujuk kepada dua buah kuasa yang mempunyai kekuatan yang setara atau hampir-hampir setara. Adakah China Komunis dan Amerika Syarikat mempunyai kedudukan yang benar-benar setara dalam semua aspek? Dalam beberapa aspek China berada di belakang daripada Amerika Syarikat dan tidak setara. Misalnya peranan dan penglibatan ketenteraan China di peringkat global belum benar-benar meluas seperti Amerika Syarikat. Pengkalan tentera China di peringkat global masih tidak standing sepenuhnya dengan Amerika Syarikat. Jadi bipolar dalam tafsiran menyeluruh tidak begitu tepat. 
Adakah tepat untuk dikatakan Asia Pasifik bersifat unipolar? Unipolar bermakna hanya terdapat sebuah kuasa sahaja yang benar-benar dominan iaitu Amerika Syarikat menjadi satu-satunya kuasa paling dominan di rantau Asia Pasifik. Jawapan dan realiti sebenarnya adalah juga tidak tepat kerana kekuatan dan peranan kuasa China Komunis tak dapat dinafikan di rantau Asia Pasifik. Amerika Syarikat bukan satu-satunya kuasa besar yang mempunyai kuasa yang dominan di rantau Asia Pasifik.

Dalam merungkai persoalan ini, penulis mengemukan kenyataan bahawa Asia Pasifik selepas Perang Dingin berakhir adalah bersifat uni-multipolar. Uni-multipolar ini merujuk kepada Amerika Syarikat sebagai sebuah kuasa yang besar dan berpengaruh, tetapi tidak bersifat unipolar. Penulis berpendapat bahawa struktur yang tepat bagi Asia Pasfik adalah uni-multipolar. Amerika Syarikat sebagai kuasa besar yang dalam beberapa aspek mempunyai pengaruh yang lebih besar, tetapi tidak sampai ke tahap unipolar. Keputsan Amerika Syarikat masih tertakluk dan perlu melihat kepada kuasa-kuasa besar yang berada di sekelilingnya. Tindakan kuasa utama dalam uni-multipolar ini (iaitu Amerika Syarikat) mesti juga mengambil kira kuasa-kuasa di sekelilingnya, salah satu daripadanya adalah China Komunis. Perkembangan yang berlaku dalam dekad kedua pasca Perang Dingin, muncul pula kuasa-kuasa seperti Russia yang bangkit semula selepas Putin berkuasa menjadi presiden pada tahun 2000. ${ }^{\text {xiii }}$ Jadi Amerika Syarikat mempunyai kuasa dan pengaruh yang kuat, tetapi tindakannya perlu mengambil kira kuasakuasa lain seperti China Komunis dan Russia (selepas tahun 2000).

\section{Apakah Struktur Kuasa akan datang yang mungkin terbentuk di rantau Asia Pasifik?}

Struktur politik regional yang mungkin terbentuk adalah bergantung kedudkankuasa Amerika Syarikat dan kedudukan kuasa besar serantau yang lain, terutamanya kuasa China Komunis dan Russia. Kuasa lain seperti India dan Jepun juga berpotensi menjadi lebih berpengaruh pada masa depan dan memainkan peranan yang lebih pentung pada masa depan.

Struktur uni-multipolar yang dinyatakan di atas akan berubah kepada satu struktur baru apabila berlaku perubahan dalam kedudukan kuasa-kuasa besar lain. Ini dapat dilihat dalam beberapa keadaan; pertama, jika kedudukan Amerika Syarikat bertambah kuat dan kuasa-kuasa regional lain bertambah lemah, struktr unipolar akan terbentu. Amerika Syarikat akan menjadi kuasa yang bersifat unipolar. Keduanya, jika kedudukan Amerika Syarikat menjadi secara relatifnya lemah, manakala dalam masa yang sama kuasa-kuasa regional yang lain (China Komunis, Russia, Jepun dan India) bertambah kuat dan mempunyai kedudukan yang sama atau hampir sama dengan Amerika Syarikat, maka struktur multipolar akan terbentuk. Jika hanya tiga buah kuasa sahaja terbentuk, maka struktur tripolar akan terbentuk semula.

\section{Kesimpulan}

Kajian ini menyimpulkan bahawa struktur tripolar adalah satu tempohmasa yang penting bagi rantau Asia Pasifik bukan sahaja kepada era Perang Dingin, tetapi juga mempunyai pengaruh yang besar terhadap struktur politik regional selepas berakhirnya Perang Dingin 1991. Tanpa terbentuknya struktur tripolar dalam tahun-tahun 1971-1991 adalah tidak mungkin bagi kuasa China komunis boleh mencapai kemajuan ekonomi yang pesat (rapid economic development) dalam tahun-tahun 1980-an dan 1990-an yang membuka jalan bagi China komunis menjadi kuasa ekonomi kedua terbesar pada akhir tahun 2010. Tanpa kekuatan ekonomi adalah tidak mungkin China komunis menjadi sebuah kuasa tentera dan politik yang kuat di peringkat serantau dan antarabangsa. Kedudukan China yang kuat dari segi politik, ketenteraan dan ekonomi mempengaruhi struktur politik regional selepas berakhirnya Perang Dingin. Kewujudan kuasa China di rantau Asia Pasifik telah menyebabkan rantau ini berbeza dengan perkembangan politik yang berlaku di benua Eropah. Setelah runtuhnya kuasa Soviet Union pada tahun 1991, tidak ada kuasa yang menyaingi kuasa Amerika Syarikat di benua Eropah. Dengan tidak wujudnya kuasa besar yang setara dengan Amerika Syarikat di benua Eropah, maka struktur bipolar telah berubah kepada struktur unipolar iaitu satu kuasa tunggal yang dikuasai oleh Amerika Syarikat. Struktur unipolar tidak terbentuk di rantau Asia Pasifik sebagaimana yang 
berlaku di benua Eropah kerana wujudnya kuasa China. Peranan yang dimainkan oleh Amerika Syarikat di rantau Asia Pasifik selepas berakhirnya Perang Dingin adalah berbeza kerana wujudnya kuasa China. Pencapaian ekonomi yang kukuh yang dilalui oleh China dalam tahun-tahun 1980-an dan 1990-an (dan seterusnya dalam tahun-tahun selepas 2000-an) telah menjadikan kedudukan China adalah berbeza dengan apa yang dialami oleh negara-negara komunis Eropah Timur dan Soviet Union sendiri. Struktur Tripolar memberikan kesan yang besar kepada pertumbuhan dan pembangunan ekonomi China komunis, khususnya dalam masa fasa kedua struktur tripolar iatu dalam tahun-tahun 1980-1991. Dalam tempohmasa fasa kedua ini China komunis menjadi kuasa paksi (pivot power). Amerika Syarikat dan Soviet Union mempunyai hubungan yang buruk dalam tempohmasa ini. Sebagai kuasa paksi, China Komunis mempunyai hubungan yang baik dengan kedua-dua kuasa, khususnya dengan Amerika Syarikat. Hubungan yang baik dengan Amerika Syarikat telah memberikan kesan yang positif kepada pertumbuhan dan pembangunan ekonomi China. Pelaburan dan hubungan perdagangan China dengan Amerika Syarikat dan negara-negara sekutu Amerika Syarikat telah menyumbang kepada pertumbuhan ekonomi China. Semua perkembangan sejak fasa kedua struktur tripolar terus menyumbang kepada kewujudan kuasa China sebagai sebuah kuasa ekonomi dan politik di peringkat regional dan global yang berpengaruh.

\section{Nota:}

i 'Actors (states) are less important because structures compel them to act in certains ways. Structure more or less determine actions.' Ini menunjukkan bahawa sesebuah state dalam struktur antarabangsa banyak dipengaruhi oleh struktur antarabangsa yang terbentuk, yang memaksa sesebuah state atau kumpulan state dalam sesebuah wilayah untuk bertindak sesuai dengan situasi struktur antarabangsa yang berlaku dalam sese uatu tempoh masa. Lihat Jackson, R, \& Sorensen, G. (2001). Introduction to International Relations, Oxford: Oxford University Press, hal. 85. Lihat juga Waltz, K. (2008).Realism and International Politics. London and New York; Routledge; Keohane, R.O. (ed.) (1986). Neorealism and Its Critics. New York: Columbia University Press.

ii Asas perbincangan struktur tripolar ini sila lihat Henderson, C.W. (1998).International Relations: Conflict and Cooperation at the Turn of the $21^{\text {st }}$ Century. Boston; McGraw-Hill, hal. 113-114; Segal, G. (1982). The Great Power Triangle.New York: St. Martin's Press; Yahuda, M. (2006), The International Politics of the AsiaPacific (second and revised edition). London and New York; Routledge-Curzon, terutamanya bab 3, The period of tripolarity, 1971-1989, hal. 72-97.

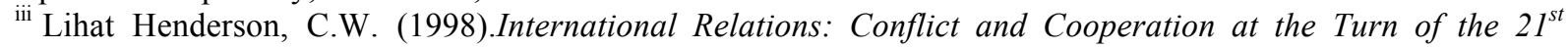
Century. Boston; McGraw-Hill, hal. 113-114

iv Lawatan Setiausaha Negara Henry Kissinger Julai 1971 dan Presiden Richard Nixon pada Februari 1972 ke China Komunis dan sambutan yang diberikan mempunyai kesan besar kepada hubungan China-Amerika Syarikat dan struktur politik antarabangsa selepasnya. Lawatan ini membuka laluan kepada pengiktirafan China Komunis sebagai sebuah kuasa besar.

${ }^{v}$ Lihat McDougall, D. (2007).Asia Pacific in World Politics. Boulder \& London: Lynne Reinner Publishers, hal.54 dan 55; dan Yahuda, M. (2006). The International Politics of the Asia-Pacific (second and revised edition). London and New York, hal. 77-85 dan 89-94.

${ }^{v i}$ Perbezaan yang paling jelas antara dua fasa ini adalah perubahan kuasa yang menjadi kuasa paksi (pivot power). Dalam fasa pertama struktur tripolar, 1971-1979 Amerika Syarikat menjadi kuasa paksa, manakala dalam fasa kedua 1980-1991 pula China Komunis bertindak sebagai kuasa paksi.

vii Perbincangan lanjut sila lihat Yahuda, M. (2006). The International Politics of the Asia-Pacific (second and revised edition). London and New York, hal. 74-85.

viii Young, J.W. \& Kent, J. (2013). International Relations since 1945: A Global History. Oxford, UK: Oxford University Press, hal. 345-346.

${ }^{i x}$ Yahuda, M. (2006). The International Politics of the Asia-Pacific (second and revised edition). London and New York, hal. 85.

${ }^{\mathrm{x}}$ Harding, H. (1992). A Fragile Relationship: The United States and China since 1972.Washington, DC: Brooking institution, hal. 91-94.

${ }^{x i}$ Lihat Kim, S.S. (2014), The Evolving Asian System: Three Transformations. Dalam Shambugh, D. \& Yahuda, M. International Relations of Asia. Lanham,Maryland;Rowman \& Littlefield, hal. 51.

xii Simone,V. \& Feraru, A.T. (1995). The Asia Pacific: Political and Economic Development in a Global Context. New York: Longman, hal. 189.

xiii So, A.Y \& Chiu, S.W.K. (1995). East Asia and the World Economy. Thousand Oaks, London \& New Delhi: Sage Publications, hal. 150-156. 
${ }^{\text {xiv }}$ Duffield, John, S. (2001). Why is There No APTO? Why is There No OSCAP?: Asia-Pacific Security Institution in Comparative Perspective. Contemporary Security Policy, 22 (2), hal. 69-95.

${ }^{\mathrm{xv}}$ Cha, Victor, D. (2009). Power Play: Origin of the U.S. Alliance System in Asia. International Security, 34 (3), hal. 158-196.

${ }^{x v i}$ Lihat Jackson, R. \& Sorenson, G. (2007). Introduction to International Relations (third edition), Oxford, UK: Oxford University Press, hal. 81-88.

xvii Keylor, W. (2003). A World of Nations: The International Order since 1945. New York \& Oxford: Oxford University Press, hal. 315-319.

xviii Yahuda, M. (2006). The International Politics of the Asia Pacific. (second and revised edition). London \& New York: Routledge-Curzon, 210-223.

${ }^{x i x}$ Keylor, W. (2003). A World of Nations: The International Order since 1945. New York \& Oxford: Oxford University Press, hal. 367-378.

${ }^{\mathrm{xx}}$ Lihat Reynolds, D. (2001). One World Divisible: A Global Historysince 1945. New York: W.W. Norton \& Company, hal. 576-585.

${ }^{x x i}$ Revolusi ekonomi yang dilakukan oleh Deng Xiao-Peng telah memberikan kesan yang besar kepada pembangunan ekonomi dan kedudukan China. Dasar yang dilakukan oleh Deng sangat berbeza dengan pimpinan sebelumnya. Perbincangan lanjut sila lihat Keylor, W. (1992). The Twentieth Century World: An International History.(second edition). New York: Oxford University Press, hal. 463-473.

${ }^{x x i i}$ Simone,V. \& Feraru, A.T. (1995). The Asia Pacific: Political and Economic Development in a Global Context. New York: Longman, hal.188-193.

xxiii Simonia, N.A. (2006). Russia in the Asia Pacific: The Beginning of a New Era? Asia Pacific Review, 13 (1), hal.16-31.

\section{Rujukan}

Cha, Victor, D. (2009). Power Play: Origin of the U.S. Alliance System in Asia. International Security, 34 (3), 158-196.

Duffield, John, S. (2001). Why is There No APTO? Why is There No OSCAP?: Asia-Pacific Security Institution in Comparative Perspective. Contemporary Security Policy, 22 (2), 69-95.

Henderson, C.W. (1998).International Relations: Conflict and Cooperation at the Turn of the $21^{\text {st }}$ Century. Boston; McGraw-Hill.

Johnson, A.I. (2013). How New and Assertive Is China's New assertiveness? International Security, $37(4), 7-48$.

Golstein, A. (2013). First Thing First: The Pressing Danger of Crisis Instability in U.S-China Relations. International Security, 37(4), 49-89.

Harding, H. (1992). A Fragile Relationship: The United States and China since 1972.Washington, DC: Brooking institution.

Ikenberry, G.J. \& Mastanduno, M. (2003). International Relations Theory and The Asia Pacific, New York: Columbia University Press.

Jackson, R. \& Sorenson, G. (2007). Introduction to International Relations (third edition), Oxford, UK: Oxford University Press.

Keylor, W. (2003). A World of Nations: The International Order since 1945. New York \& Oxford: Oxford University Press.

Keylor, W. (1992). The Twentieth Century World: An International History.(second edition). New York: Oxford University Press.

Keohane, R.O. (ed.) (1986). Neorealism and Its Critics. New York: Columbia University Press.

Kim, S.S. (2014), The Evolving Asian System: Three Transformations. Dalam Shambugh, D. \& Yahuda, M. International Relations of Asia. Lanham,Maryland;Rowman \& Littlefield, hal. 33-58.

Liff, A.P. \&Ikenberry, G.J. (2014). Racing toward Tragedy? China's Rise, Military Competition in the Asia Pacific, and Security Dilemma. International Security, 39(2), 52-91.

Murray, D. (2013). The Chinese Dragon. Dalam Murray. D \& Brown. D. (eds). Multipolar in the $21^{\text {st }}$ Century: A New World Order. London \& New York: Rouledge, 48-79.

Ong, R. (2006). China, US and the North Korea Issue. Asia Pacific Review, 13(1), 118-135.

Reynolds. D. (2001).One World Divisible:A Global History since 1945. New York: W.W. Norton \& Co. 
Schweller. R.L \& Xiaoyu Pu. (2013). After Unipolarity: China's Visions of International Order in Era of US Decline. International Security, 36 (1), 41-72.

Simone,V. \& Feraru, A.T. (1995). The Asia Pacific: Political and Economic Development in a Global Context. New York: Longman.

Simonia, N.A. (2006). Russia in the Asia Pacific: The Beginning of a New Era? Asia Pacific Review, 13 (1), 16-31.

So, A.Y \& Chiu, S.W.K. (1995). East Asia and the World Economy. Thousand Oaks, London \& New Delhi: Sage Publications.

Yahuda, M. (2006). The International Politics of the Asia Pacific. (second and revised edition). London \& New York: Routledge-Curzon.

Yahuda, M. (2006a). The Post Cold War Order in Asia \& The Challenge toASEAN. Pasir Panjang, Singapore: Institute of Southeast Asian Studies.

Yazid, M.N. (2017). Asia Pasifik sejak 1945: Perubahan Struktur Antarabangsa dan Percaturan Politik Serantau. Kuala Lumpur: Institut Terjemahan dan Buku Malaysia (ITBM).

Young, J.W. \& Kent, J. (2013). International Relations since 1945: A Global History. Oxford, UK: Oxford University Press. 